\title{
Professional Identity Representation in a Successful Intercultural Communication: A Socio-Cognitive Perspective
}

\author{
La Ode Alfin Haris Munandar*; Lalu Muhaimi; Nawawi \\ English Graduate Department, University of Mataram, Indonesia \\ Email: harisalfin91@gmail.com
}

http://dx.doi.org/10.18415/ijmmu.v5i6.509

\begin{abstract}
Aims of this research were to analyze the representation of professional identity through the language use in email correspondence, the way it was achieved, and its implication toward a successful intercultural communication. The model of analyzing the language usage in this research was based on Van Djik's socio-cognitive perspective (2018) and the work of Patel, et. al (2011) in which they argue that the language usage is a result of mental processing. The mental processes in this research was specified into conclusion withdrawal about other culture which then used for an effective intercultural communication and intended to be a successful one. This research was qualitative in nature in which it was described descriptively. The source of the data in this research was the email correspondence conducted by the employees of Adventure Lombok Tour and travel. The data were collected through observation and transcript analysis. The results of this research indicated that the employees of Adventure Lombok company were indeed represented their professional identity, this professional Identity was reflected and accomplished through a variety of ways which were consideration toward their customers preferences, a prompt and accommodating reply, providing honest suggestion, and service oriented which then lead to a successful intercultural communication that can be seen from the sells that the employees made. All of these were believed to be the result of previous 'intercultural contact' which were stored within the cognitive of the employees and retrieved for later use. This result is in line with Li and Patel (2011: 22) in which they argued that "intercultural communication is influenced by the quality of the intercultural contact that we have in our personal and professional environments".
\end{abstract}

Keywords: Professional Identity; Representation; Intercultural Communication; Socio-Cognitive

\section{Introduction}

Identity is an abstract, complex, and dynamic concept which is not easily defined yet interesting to be analyzed. It deals with the way people affiliate as well as distance themselves from certain communities, the meaning that they convey in social context and in turn produce the ideas of others toward themselves. In doing so, the use of language tends to be crucial in representing, constructing, and negotiating identities. As stated by De Finna (2010) people use language to convey self-image, identify others, classify and judge other people, and group oneself in order to signal similarities and differences. In this view, language and discourse is seen to be the central of the construction and negotiation of identities. 
Thus, this current study focused on the representation of professional identity in email correspondence conducted by non-native speaker on one of travel agency in Lombok, the way they achieve that professional identity, and its implication in successful intercultural communication.

Furthermore, identity is seen to be social factors in which it is acquired during the growth of a person. In other word, social identity is not something that human born with; rather it is something that human constructs during his/her growth (Fearon., 1999). In addition, the social identities that have been acquired by certain individual are not permanent, it continues to evolve and shift from one identity to another as the time goes on Bloome et. al (2005). Identity also plays an important role in communication, according Sooknanan (2011: 98) "for effective communication between groups of people, each of the groups will have to acquire, learn or have adequate knowledge about each other's culture before they begin to draw conclusions about each other's believes, attitudes, and behaviors in a particular situation". This means that the consideration of identity is important in effective communication since believes, attitudes, and behaviors are central to identity.

Based on this view, this research was aimed to analyze the representation of professional identity through the language use. In doing so, it would also be necessary to consider the place where language is being processed. It has been generally understood that language process occurs within human mind. However, the language process is a broad term which also includes the acquisition of language. Hence, the language process here is limited to the way humans use language to communicate their identities. However, this process of understanding a language when communicating is only a small part of a larger process which also includes process of thinking, perceiving, knowing, believing, interpreting, planning, hoping, etc. Such process is known as 'Cognitive Processes'.

According to Van Djik (2018: 29), "Cognitive processes and representations cause and control all human action and interaction and hence also all language use and discourse". In addition, Patel, Li, and Sooknanan (2011: 42) stated that "when we are confronted with people from diverse cultures, we immediately activate our mental models and begin our mental processing...".

It seems that what Van Djik refers to as cognitive processes and what Patel, et. al. call as mental processes are the same thing because the results of cognitive processes or mental processes are the same in which the results are represented in human attitudes or behaviors where both Van Djik and Fatel, et. al. agree to call this representations as 'Mental Representation'.

Furthermore, the cognitive processes stated earlier become the base line of choosing SocioCognitive as the approach of this study. According to Van Djik (20018: 28) "socio-cognitive includes cognitive interface and claims that there is no direct link between different structure such as discourse and society, and that social structures can only affect text and talk through the minds of language users. This claim makes the analysis of identity through the use of language available since language usage is also one of the forms of mental representation.

\section{Short Overview of Adventure Lombok Travel Agency}

Adventure Lombok Tour is licensed tours and travel agency from Lombok island, Indonesia which is located in Senggigi. As a member of ASITA (Associations of The Indonesian Tours \& Travel Agencies) and ATTA (Adventure Travel Trade Association), Adventure Lombok Tour does not only offer tours around Lombok, but also includes several parts of travel destination in Indonesia such as Raja Ampat in Papua, Komodo Island in East Nusa Tenggara, and Kalimantan. Adventure Lombok Tour was established in 2009 and continues to operate until this research was conducted. Furthermore, this travel 
agency specialized in organizing private tours in which its customers may organize their own travel itinerary which makes email correspondence is a necessity.

In addition, Adventure Lombok Tour and travel specialized in organizing tours for oversees customers. Most of their customers are from Australia, Europe, and Singapore. This customer's specialization was the main reason for choosing Adventure Lombok Tours as the source of the data, since this research requires its data which are collected from the interaction of various social backgrounds.

\section{Methodology}

This research is qualitative in nature in which it was described descriptively. Thus, this research used descriptive-qualitative as its design. Following the descriptive-qualitative introduced by Flick (2009) in which he argues that descriptive-qualitative can be used in analyzing local, temporal, and situational phenomena. The source of the data was the transcription of email correspondence of employees of Adventure Lombok travel agency with their customers. However, in order to avoid any deviations, only the emails that has the sense of identity that was collected. Those emails were analyzed qualitatively and based on socio-cognitive perspective. In addition to transcript analysis, the data was also supported by the result of observation in which it is intended to support the analysis of the transcription of the emails.

\section{Results and Discussions}

From the observation and transcript analysis, it was found that the employees of Adventure Lombok Tours and travel represented their professional identity in the email correspondence with their customers. This professional Identity was accomplished through a variety of ways such as considering their customers preferences, giving a prompt and accommodating reply, providing honest suggestion, and service oriented.

\section{Customers Preferences Consideration}

From the transcripted email correspondence it was found that this travel agency did not egoistically offer their products. Instead, they asked their customers first before giving a suggestion. For instance,

Extract 1. Customers' and Employees’ Emails

Greetings All!

I have been looking at your site, Adventure Lombok, and I have been drawn to the cultural, historical, and scenic activities within your packages. My fiancé and I are very interested in the honeymoon package. Though, I have a few quick questions to get to know your area better. Which hotel/bungalow do you partner with? Also, do you have pictures of the hotel and rooms?

Employee's Replay

Warmest greeting from Lombok

Thank you for your email, regarding to your request for the package, please advise what kind of accommodation that you would like to have (4 star hotel, villa with private pool and the location you choose on the beach, in the city or in the hill). 
From the extract 1 above it can be seen that it was the customers' first time for making Lombok as their travel destination, it was reflected on the existence of a question which is intended to know more about the area of Lombok. And this intentional question marked the identity of a 'first timer'. In order to response to the customers' question, the employee replied the email by asking for advice regarding their customers' preferences with a few options to choose. In doing so, the employees, whether he realized it or not, tried to narrowed down the preferences of the customer so that he could provide a right-on-target replay. Actually, the employees had an option to directly offer a package to his customers, but he chose to ask the customers first and this decision represented his professional identity. This result is in line with Atkins, et. al. (2005) in which identity includes standard for behavior and decision making.

\section{Prompt and Accommodating Reply}

When looking for service providers especially for travel planning, people generally tend to look for variety of options in the internet. Thus, they might send a lot of emails to different companies. In order to compete with the other travel agencies that the customers send an email to, the employees provided a fast reply, however it was not only fast but also provide an accommodating reply which depends on the customers' needs. The extract 2 below showed a customer's email.

Extract 2. Customers' emails

$\mathrm{Hi}$,

Thanks for your prompt reply and the offer made. The itinerary looks fine to me.

May I know for the accommodation quoted based on how many rooms?

Is it possible to change the hotel to Sheraton Senggigi instead \& we need two rooms.

We might want to extend our stay for another 2 days but will be on free \& easy to another hotel of our choice. Will it be possible for you to arrange for the transfer to the other hotel \& book the rooms for us too?

$H i$

Thanks for your prompt reply.

May I know upon confirmation, how much do we need to upfront for deposit?

Is it ok for the temple tours, can you bring us to other places instead?

How much is the airport tax in Lombok?

Not only provided a prompt reply, the employees of Adventure Lombok also provided an accommodating reply which is intended to answer the customers' email as well as giving suggestion if the requests were likely impossible to be done.

Extract 3. Accommodating Replies

Greetings

Thank you for your email

Referring to your email, we afraid that you won't have enough time to visit the North waterfalls

(Sendang Gile and Tiu Kelep) if you start the trip from Lembar harbor

But here, we suggest you another waterfall that you may visit during your time limit

Please refer to the quotation that we have attached along with this email for your reference regarding the itinerary and price 
Hope the information above is helpful, we are looking forward to any update from you

Thank you for your update

Yes of course, we could rearrange the itinerary for you

Please find the revised quotation that we have attached along with this email for your reference,

The Northern excursion and the waterfall trip are basically a same trip, but the northern excursion

has a more place to visit than the waterfall trip

Also the northern excursion is already on the third day of your honeymoon package.

\section{Honest Suggestion and Opinion}

The third way of professional identity representation was found in the way the employees provided a real condition regarding the package. They would state that the trip would be impossible if it was truly impossible. However, if the customers agreed to do the impossible, the company would prepare a solution for the conditions, as well as giving suggestion on what to do and prepare for those trips. Extract 4 below showed the way the professional identity was reflected on the employee of Adventure Lombok Company.

\section{Extract 4. Suggestion and Opinion}

\section{Greetings}

We will update you as soon as we get an update from the hotel

As for visiting Pink Beach on the last day, I think it will be too risky for your flight since the travel time from Senggigi to Pink Beach will take about 3.5 hours drive and from Pink Beach to airport will take another 2 hours drive

We could organize it but you need to start this trip from your hotel the latest at 07.00 AM

\section{Greetings}

Thank you for your email

I recommend running or biking once day. You don't have to do some heavy exercise actually, I am afraid that you will get injured if you push your body, so sustainable light exercise would be enough and have good rest during the night

If you are used to running, biking, or you usually go to the gym, then you just need to keep doing it Hope the information above is helpful

\section{Service-Oriented}

The result from the interview with all the employees of Adventure Lombok Tours and Travel indicated that they avoided the mind set of money orientation. Their motto is to provide the best service, if the service makes the customers satisfied, they believe money will come to follow. The interview also indicated that this company was not afraid of refunding the customers payment if the services were to be unbeneficial for the customers. 
Extract 5. Transcription of recorded interview

'kebanyakan batur-batur travel lek te ye luekan pade mikir kepeng doang lek otak ne ndkn pade pikiran service jek tamu. Jarin lamun wah pade mauk kepeng jak wah, ndkn puti pade peduli berembe kedaan lek lapangan. Lamun ite jak ndk te menu, pokok service bejulu, lamun wah bagus service jak kepeng ye nurut mudi. Selain mauk te kepeng ye jari bahan promosi laun, kan lamun puas tamu pasti ne jak becerite jek batur-batur ne. Jari ne promosi geratis buat kantor ite.'

'most of fellow travel agency here think about money and do not care much about service. As long as they have got the money, they won't think about the condition during the trip. We don't do that, we think of service first, if the service is good money will come to follow. Besides money, it could be our promotion. If the customers are satisfied, we believe that they will tell their friends and that is free promotion for our company.'

\section{Implication of Professional Identity in Successful Intercultural Communication}

The standard of measuring whether the communication was successful or not in this research was the successful of selling a product. The result of this research indicated that the employees were successful in selling their products because of their professional identity which is believed to be the result of their 'intercultural contact'. This result is in line with Li and Patel (2011:22) in which they argued that "intercultural communication is influenced by the quality of the intercultural contact that we have in our personal and professional environments".

Furthermore, this professional identity was reflected on the use of the language, it is believed that the 'intercultural contact' that have been experienced by the employees of the Adventure Lombok was processed within their cognition which than stored in their Long Term Memory for later use. Thus, the result of previous 'intercultural contact' which built the professionalism of Adventure Lombok employees can be seen on the language that they chose to use in dealing with their customers which then resulted in their product being sold. This result is in line with Van Djik (2018), short term memory or working memory is the place where all incoming information from various senses is analyzed and interpreted including aspects which are specific to language such as phonological, morphological, syntactical aspects, as well as social and cultural aspects such as values and believes . Long Term Memory, on the other hand, takes the role of a storage in which all the results of working memory is stored. Apparently, the process of thinking, understanding, and perception take place in working memory which then stored in the Long Term Memory for later use. However, this does not mean that human can remember all the information that has been placed on the Long-Term Memory, it depends on the process of retrieval of that information.

\section{Conclusion}

The result of this study revealed that professional identity contributed an important role in conducting a successful intercultural communication. This was achieved through a variety of ways that are considering the customers preferences, prompt and accommodating reply, giving honest suggestion and opinion, and providing service based orientation. All these act of considering, replying, giving, and providing were reflected on the language that was used in the emails and marked their professionalism. 


\section{References}

Atkins, R., Hart, D., and Donnely, T.M. (2005). The Assosiation of Childhood Personality Type with Volunteering During Adolescence. Meril_palmer Quarterly, 51(2):145-142.

Bloome, D., Carter, S.P., Chirstian, B.M., Otto, S., Shuart-Faris, N. (2005). Discourse Analysis and the Study of Classroom Language and Literacy Events. London: Lawrence Erlbaum Associates Publishers.

De Fina, Anne. (2010). Discourse and Identity. In T.A. Van Djik (Eds.). Discourse Studies: A Multidisciplinary Introduction. London: SAGE Publication, 1: 263-282.

Fearon, J. D. (1999). What is Identity (As We Now Use the Word)? California: Stanford University.

Flick, U. (2009). An Introduction to Qualitative Research 4th Edition. London: Sage Publications.

Patel, F., Li, M., and Sooknanan, P. (2011). Building a Global Community. In Fay Patel, Mingsheng Li, and Prahalad Sooknanan (Eds). Intercultural Communication: Building a Global Community, New Delhi: Sage Publications. Page. 5-14.

Sooknanan. (2011). Intercultural Communication in the Global Workplace. In Fay Patel, Mingsheng Li, and Prahalad Sooknanan (Eds). Intercultural Communication: Building a Global Community, New Delhi: Sage Publications. Page. 90-120.

Van Dijk, T. A. (2018). Socio-Cognitive Discourse Studies. In John Flowerdew and John. E. Richardson (Eds). The Routledge Handbook of Critical Discourse Studies, pp. 26-43. New York: Routledge.

\section{Copyrights}

Copyright for this article is retained by the author(s), with first publication rights granted to the journal.

This is an open-access article distributed under the terms and conditions of the Creative Commons Attribution license (http://creativecommons.org/licenses/by/4.0/). 